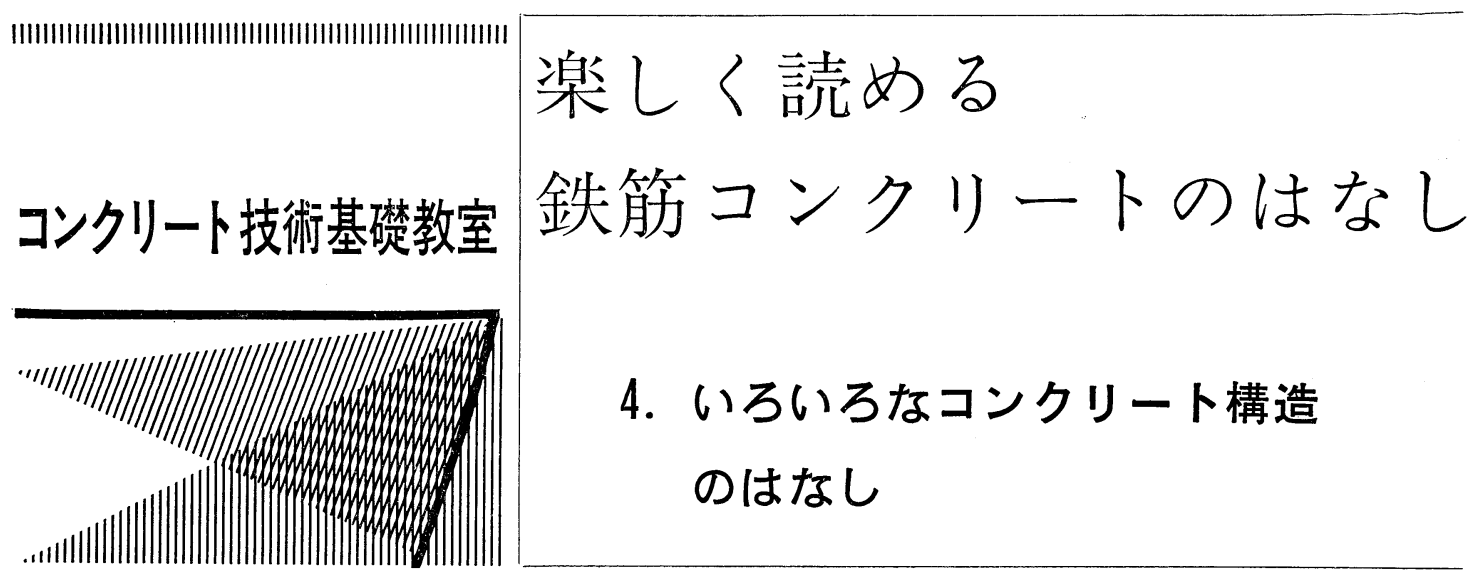

（第 12 回・終）

\title{
4.1 土木のいろいろなコンクリート構造
}

1。ある工事から

まず図一1を見てください。これは，国電桜木町駅付 近に作られているさまざまな構造物を, 平面的に重ねて 示したものです。これでは立体的な関係が分かりにくい ので, 地上から地下まで, 断面を切りながら図示したの が図一2です。このような複雑な構成をしている構造物 も，でき上ってしまうとその上下関係が分かりません。 地上を走っている国電の空からは, 他の構造物との関連 は多少は分かりますが, 地下を自動車や地下鉄で通り抜 ける時は, 全然分からないと思います。現在これらの構 造物が，ほとんど同時に施工されていますので，この現 場を見ることで, 土木のいろいろな構造物の形を観察す ることができると思います。今回は題目に合せて，この

\section{目次}

1. プロローグ

1.1 コンクリートでできているもの(Vol. 14, No. 1 揭載)

1.2 コンクリートが使われるわけ (Vol. 14, No. 2 揭載)

2. 橋のはなし

2.1 コンクリート橋の種類 (Vol. 14, No. 3 掲載)

2.2 橋にはたらく荷重（同上）

2.3 けたはどうやって造られるか (Vol. 14, No. 4 揭載)

2.4 床版はどうやって造ら机るか (Vol. 14, No. 5 揭載)

2.5 橋脚の設計について考えよう（Vol. 14, No. 6 揭載）

3. 建物のはなし

3.1 骨組の選び方と設計 (Vol. 14, No. 7 掲載)
現場を紙上で御案内しながら，土木のいろいろなコンク リート構造を御紹介しましょら。

一番下を通っているのは,横浜市営の地下鉄 3 号線で, 地下約 $30 \mathrm{~m}$ の所にあります。これは,切り口から見てお 分かりになるように円形をしており, 大部分はシールド

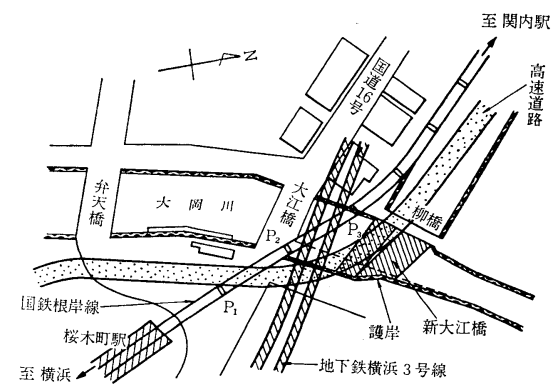

図-1 横浜 ·桜木町駅付近工事現場平面図

\section{2 はりや柱はどうやって設計されるか}

(Vol. 14, No. 8 揭載)

3.3 スラブはどうやって設計されるか

(Vol. 14, No.9 揭載)
3.4 壁はどうやって設計されるか （同 上）
3.5 建物の基礎はどうやって造られるか（同上）
3.6 特殊な鉄筋コンクリート（Vol. 14, No. 10 揭載）
3.7 鉄筋コンクリート建築の工事のあらまし（同 上）
3.8 プレストレストコンクリートを使ったラーメン

(Vol. 14, No. 11 揭載)

4. いろいろなコンクリート構造のはなし

4.1 土木のいろいろなコンクリート構造

4.2 建築のいろいろなコンクリート構造

5. エピローグ 


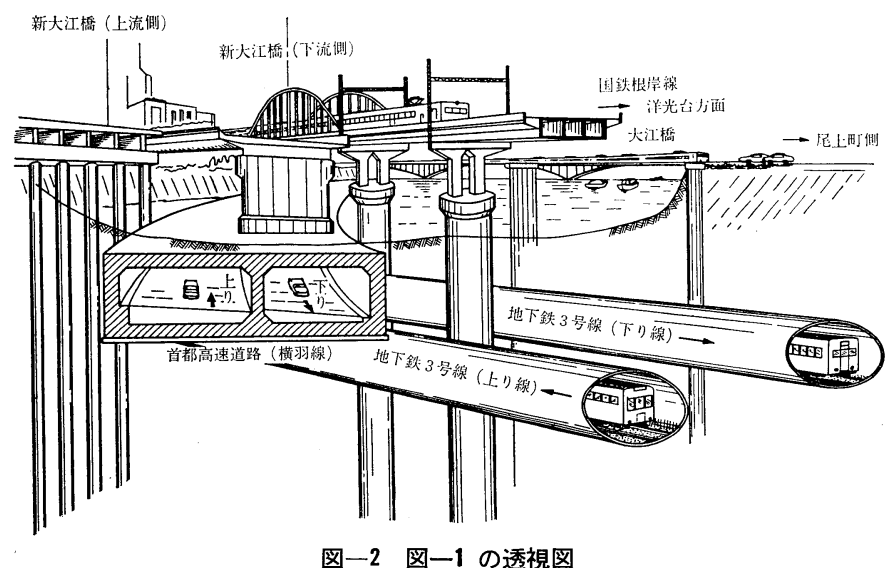

図-2 図一1 の透視図

工法といら特殊なトンネルの作り方でできたものです。 この工法は, 後程詳しく説明しますが, 近年多くなった 工法で, 都心の多くの地下鉄や電話・電力ケーブルを入 れたり，下水を流すための洞道といわれる一種の地下を 通る管路によく使われます。その上にあるのは首都高速 道路の横羽線で, 一種の水底 (河底) トンネルです。こ のトンネルの上は大岡川という川が流れており, 艀が横 浜港へ出入りしています。この川には大江橋が架ってお り, これは国道 16 号線の重要な橋です。この国道 16 号 線は, 一般の人の通行に役立つことは勿論のこと, 東京 の外郭を取巻く幹線道路として大活躍している路線で す。その上の高架になっている部分は, 国電の根岸線が 走っている路線です。図には写っていませんが，空には 当然飛行機が飛んでいますので, ここでは六重立体交差 していることになり，ほとんどの交通機関が集っている ことになります。

ではそれがどのような関係にあるか調べてみましょ う。一番昔からあったのは, 艀の交通のため大岡川でし ょう。その次は川を渡っている大江橋で, 大正年間に架 けられたそうです。大分長持ちしましたが, 寄る年波に 勝てず老朽化しており, 交通荷重の増加もあって危険な 状態になってきましたので, 今回の付近の大工事を期に 架替えることになりました。次にでき上ったのは，国電 の根岸線です。現在は全線開通し, 桜木町駅と大船駅を 結んでいますが, この部分の開通は早く昭和 30 年代の 初期の頃に完成していました。昭和 51 年にほぼ完成段 階に入ったのが, 地下鉄（昭和 51 年 9 月開通）々高速 道路です。大江橋は一足早く開通し, すでに大量の交通 を通しています。その他に, 横浜市道山下長津田線の新 大江橋（後に, 桜川橋と命名）が大江橋のバイパス的意 味合いで，この工事と同時に着工され，目下工事を進め ているところです。

今述べたように, 今回の工事は多くの事業主体と関係 があります。地下鉄と市道を作るのは横浜市,横羽線は首
都高速道路公団, 大江橋の架替えと国道 16 号線の管理は建設省，根岸線の管理は日本国 有鉄道，大岡川を管理しているのは神奈川県 といった具合です。さらに全体的に交通を 把握しているのは県警察本部であり, 水上で は海上保安庁む関係してきます。それぞれの 関係機関の協力で, 始めてこの大工事が着工 できた訳です。都会の工事は，これほどでは ないにしても，色々な機関が絡んできます。 全体の工事費となると，それぞれの事業主体 別に，年度毎に支出していますので，判然と しまんせが，オーダーをつかんでいただくた めに示しますと，300 億円以上にはなるでし 上う。横羽線だけでも，トンネルの $1 \mathrm{~m}$ の長さを作る のに 2000 万円以上は使っています。

\section{2.この工事を技術面からみると}

次に，この工事でコンクリートやセメントがどのよう に使われているか，見てみましょう。地下鉄のシールド や高速道路のトンネルは勿論コンクリートですし, 大江 橋や新大江橋の基礎のくいの一部や橋脚もコンクリート です。根岸線の基整は, 井筒といわれる1本の筒形の太 いくいですが，これもコンクリートでできており，その 上の橋脚をコンクリートです。図には入っていません が, 根岸線の橋げたには, P C 鋼材という特殊の鋼材で 補強されたプレストレストコンクリートが使われていま す。さらに大岡川の護岸は, コンクリート矢板といわれ るコンクリートの板状のものが一部に使われています。

これほどの大規模な工事になりますと, この本体を作 るために色々な仮設の構造物が必要になります。それに は本体とは異なった形で, コンクリートやセメントが使 われます。河の水をせき止めたり，土がくずれないよう にしてトンネルに必要な空間を掘っていくためには, 地 中深くまで壁を作って保護します。この工事では, 連続 地中壁というのが使われていますが，これは地中に壁状

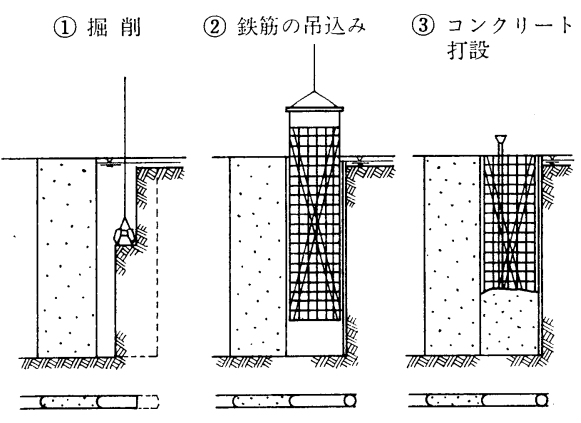

図一3 連続地中壁施工の一例 
に穴を掘り, 掘削中の土圧に対しては泥水と呼ばれる比 重の高いある細かい粉末を溶かした水で抵抗しつつ，掘 削終了後鉄筋を入れ，泥水を排除しつつ生コンクリート を投入して壁を作る方式です。もら一つは，鋼管パイル 止水壁といわれるもので, 河の中に栈橋上からパイプ状 の鋼管を次々と繋げながら打込み，壁を作って河の水を 止めるのです。その際, 継目から水が洩れるのを防ぐた め, セメントと他の溶㓮の入っている溶液をグラウト

（注入）します。さらに鋼管だけは剛性が足らず，水や 土の力でたわみすぎて危険になるので，その中を掘りコ ンクリートを打込んで補強しました。また根岸線の橋脚 のすぐ横でトンネルの穴を掘るので, 地盤を強化して橋 脚が動かないようにするグラウトを行いました。これに むセメントが入っています。桜木町の駅前は交通の多い 所ですので，交通止めをして工事を行うことはできませ ん。そこで, 夜の交通の少ない時を狙って交通制限を し，陸上のトンネルのための掘削を行いましたが，昼間 はその上に蓋をして交通を通しました。これは都会の地 下鉄の工事現場でみられるのと同じように覆工板が使わ れます。これも大部分は, コンクリートの板でできたも のを使いました。今まで述べてきたのは全体ではありま せんが，それでも如何に多くのコンクリートがいろいろ な形で使われているか, お分かりいただけたと思いま す。このように, この一帯の工事には, 現在の土木で考 えられるほとんどすべての形でのコンクリートが，本体 から仮設まで使われている訳です。

では, この工事がどのように行われたか, ごく簡単に 書いてみましょう。この大岡川は, 洪水河川で, 洪水期 に河の流れを阻害する工作物を作るのは, 洪水の原因に なるので禁止されており, 渴水期だけが河の中で工事が できる期間です。まず最初に高速道路の空間を作るた め，河を半分に楴切る鋼管パイルを打込みました。前に 述べたように, トンネルの掘削が進んで行くと土圧や水 圧が大きくなるので色々な手当をしましたし，根岸線の 橋脚の移動防止のために, ミルク状の溶液を地盤の中に 注射する形で注入しました。トンネルの屋根にあたる部 分 (上床版) まで掘り進んだ時が丁度, 渴水期の終りで す。すぐに上床版の型わくを用意し，鉄筋を並ベてコン クリートを打ちました。その後, 締切の鋼管の上床版より 上側部分を水中で切断して, 全川に亘って河の水を流し ます。図一4 は,トンネルの断面に直角に切った状態を 示したものです。点線の部分が切断したものです。河の 流れの下側では, トンネルの掘削がどんどん進められ， 上床版から鉄筋をはうり出して, 下側の鉄筋と結束し, 全ての配筋を終ったところで, コンクリートを打設して トンネルの形に仕上げます。

一方, 大江橋の工事も, 同様に河の中の橋脚の 1 本が施

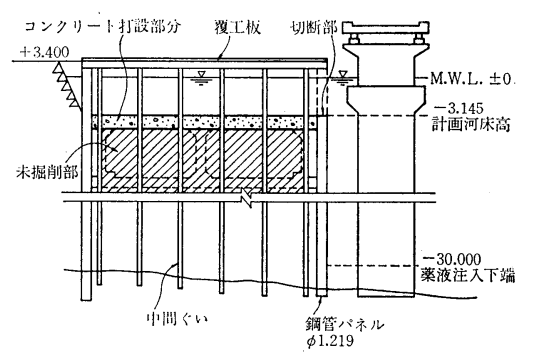

图一4 高速道路施工中の断面図

工されます。河の中に円形の鞛を打込み，その中の土を 掘出しながらその鞘を押込んで行き, 所定の深さまで掘 り進んだところで, 鉄筋を入れてコンクリートを打って くいを仕上げます。そのくいの頭を慗ぐコンクリートの 枕ばりと呼ばれるものを作って, 橋脚は完成です。新大 江橋の方も同じ方法で作られますが，一部橋脚がトンネ ルの上に乗る部分は, 締切の中で脚を仕上げてしまいま す。次の渇水期には, トンネル, 橋りょうとも反対側を 構築します。

反対側が終了しても, トンネルの工事は終っていませ ん。道路の下に地下鉄が作られるので, 工事はこれから です。トンネルと地下鉄が離れていると, シールド工法 で一気に構筑できますが，この工事では駅舎をそのため に媣くできないことや, 電車の軌道のこう配制限のため に，トンネルと離す訳に行かず，一体の構造になりまし た。道路トンネルの下に, シールドがすっぽり入るだけ の断面をこれから作ります。地下 $30 \mathrm{~m}$ にもなると, ど んな頑丈な土留でも, 土圧には耐えることができませ ん。そこで圧縮空気を地上から送りこんで, 空気の力で 土留の壁を土圧側に押し戻す方法を取りました。この方 法は, ケーソン工法に似ていますが, 今回はケーソンほ ど圧縮空気の量を多くしなくてすみました。このよう に, 土圧に抵抗しながら地下鉄の断面を道路トンネルと 同じょうに作りました。図一4に示すように,トンネル 上床版, 下休版が止水の壁と密着しており, これも一種 の土圧に抵抗する圧縮材です。この他にも, 切ばりと呼 ばれる鋼材が途中ところどころに入れられて, 土圧に抵 抗しますが，この地下鉄部分では鋼材を長物で般入が困 な難ため, 鉄筋コンク リートの切ばりが使わ れています。

一方, 地下鉄のシー ルドは，陸上に設けら れた立て坑 (真直ぐに 哚い穴) から発進して きます。このシールド は，地下鉄断面よりや や大きめな円形の断面

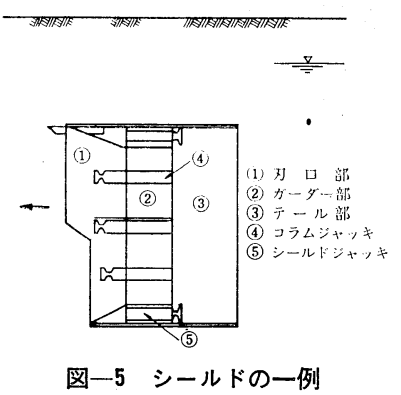
コンクリート工学 
をしており，刃口部といわれる部分が，地中で前方の土 砂を切崩しながら前進し, 中の土を後方に送って地上に 搬出し, 地中に空間を作る工法です。この刃口部に続い ては,ガーダー部と呼ばれるものがあります。これは, 最後のテール部といわれる所でセグメント（一種の輪切 りのブロック) を組立てて, 前方に送り出された部分で す。このガーダー部は, 地中の空間を確保し, 土の崩壊 を防ぐ役目をするところですが，そのセグメント同士の 継手は苦労するところです。水が洩れるのを防いだり, 地山が刃口部で崩落ちるのを防ぐため, 上に述べたと同 じように,圧縮空気が送り込まれることもあります。シー ルドが前へ進んだ後,すべり出す型わくが移動し始め,内 装のコンクリートを打設して地下鉄断面は完成です。こ の場合は, コンクリートポンプと呼ばれるコンクリート を液体のように圧送する機械が使われるのが普通です。 今回の工事では, 先程述べたように, 半川ずつ施工す る制約があったために, シールドの行く手には, 鋼管パ イルの止水の壁が控えています。シールドがこの止水の 鋼管パイルの壁にぶつかった時に，もら一つの難関があ る訳です。シールドが鋼管パイルに密着したところで, すでにでき上ったトンネルの下の地下鉄の箱の部分か ら, ガスや電気で, このパイルの林をシールドが通り抜 けれるように剞り開けました。その後に, この箱の中に シールドが入ってくる訳です。この箱の中ではセグメン トを継足すだけで掘削を行ら必要はなく, 前進させるだ けです。護岸側の鋼管パイルも同様にして刳り抜き, 河 の下と同じく, シールドは前進を続け, 到達立て坑まで 進んだところでシールドの工事は終りになります。パイ ルを切断したとき, 河の水が地下鉄の箱に入らないよう に, その周辺には, 止水性のあるグラウトがなされたこ とは勿論です。これから後は, 軌道を布設したり, 電気 関係の工事が行われます。高速道路の方も, 同様な内装 が行われています。

地上では, 大江橋や新大江橋の橋げたが架けられてい ます。と同時に河川の護岸を作るために,コンクリートの 矢板や鋼の矢板が打込まれる工事が進められています。

以上, 一つの工事現場を通して, 土木のいろいろなコ ンクリート構造のお話をしましたが，お分かりになりま したか。話を分かり易くするために,大胆に省略したり， 細い所では, 実際の工事方法と異なる説明をしましたが, 一般的な説明といらことで御容赦下さい。
について述べましたが，今度は，他のトンネルの作り方 を簡単に述べてみましょう。

学問的には,トンネルはどんな構造を指すのでしょう か。土木工学ハンドブックに述べられた定義によると,

「最終的に地表面下に位置して使用され, 何らかの方 法で所定の形状寸法に作られた空間で, 断面積が 2 $\mathrm{m}^{2}$ 以上のもの」

となっています。用途もさまざまで, 鉄道, 道路などの 交通の便に供されるもの, 水力発電, 潅溉用の水路とし て使われるもの, 上下水道, 電線路, 地下発電所, 地下 自動車駐車場，地下鉄，地下街などの地下の通路として 利用されるものなどがあります。

トンネルとして皆さんが身近 に感じられるのは, 山岳部のト ンネルでしょう。これは, 図一 6 の形をしたのがもっとも一般 的で, 人力, 機械力, 又は発破 図一6 山岳トンネル の断面

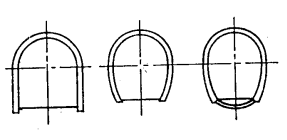
などの力を借りて，ほぼこの形に岩石を切り崩し，その 内側を何らかの方法で形を整えつつ, 土や岩石の重さに 耐える工作物を作ったものです。この工事は, 岩石の掘 削にどの方法を用いるか, 掘った後永久的な工作物を作 るまで, どのような方法で上や横からの土や岩石に耐え る支えを作るか, 覆工をどのようにするかの検討が必要 です。覆工は, 将来の目的に合せて断面を形成するもの で，通常はコンクリートが使われます。

次に,一般的なトンネルは,都市の地下鉄工事現場でみ られる開削工法のトンネルでしょう。これは, 図一7で 示されるように, 地表面より掘下り, 地下の所定の位置 に構筑物を作り, その上を土砂で埋戻して元通りに復旧 する工法です。先程の高速道路のトンネルもこの開削工 法の一種ですが, 上床版のコンクリートを先に打設した のが，一般とは異なるところです。普通は,下床版から， 壁, 上床版とコンクリートを打設していきます。この工 法で問題となるのは,土留めのための両側のくいです。土 質がよいところではあまり問題になりませんが，土質の 覀いところでは, 剛性の強いもの（鋼管ぐい, 連続地中 壁など)を使う必要があります。普通はこの土留めのくい が土圧で内側に倒れないように切ばりをしますが, その 切ばりが作業空間を小さくするので, くいを外側にアン カーした P C 鋼棒などで引張り, 作業空間を広くした土 留めアンカー工法もあります。また全断面を同時に作 らずに, 一部だけを地中に作り，残りを掘削してそれ

\section{3.トンネルの いろいろ}

前節では，トンネルの一つ の作り方であるシールド工法

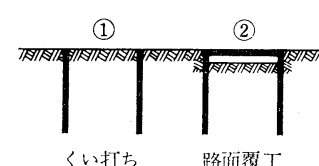

くい打ち

路通覆工

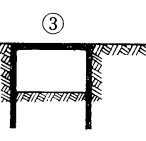

掘削開始

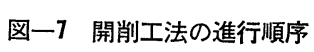




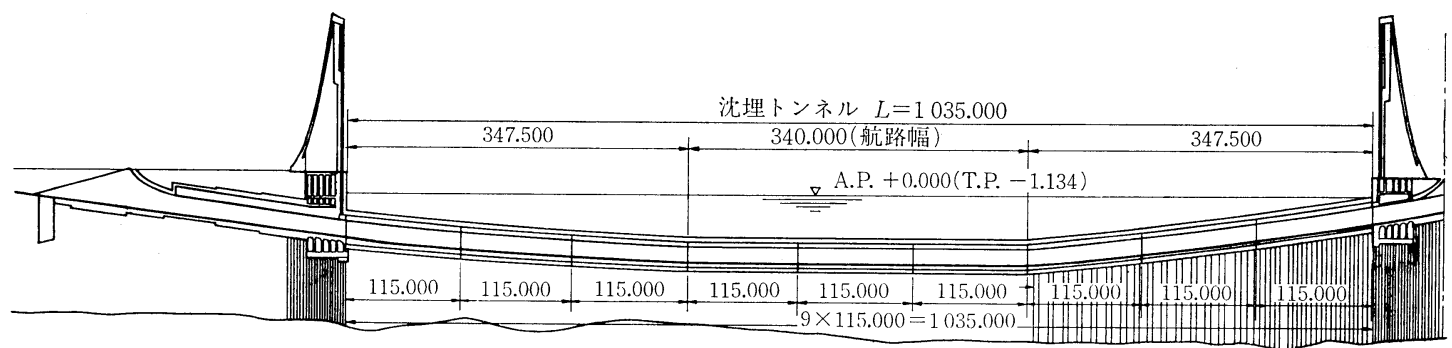

図一8 湾岸線沈埋トンネル断面図

と慗げるトレンチ工法,建物の下にトンネルを作る時に， その建物を支える工作物をまず作り，それに建物の荷重 を移して，トンネルの掘削をするアンダーピニング工法 もあります。

もら一つ変わった工法に沈埋工法といらのがありま す。これは地下の橋といってもいいものです。今年開通 した首都高速道路の湾岸線もこの工法で作られたもので す。これは, セグメントと呼ばれるコンクリートもしく は鋼製の箱を予め作っておき, 所定の水面までえい航し て沈設し,慗ぎ合せてトンネルを仕上げるものです。この 工法は, 19 世紀末から実用化され, アメリカ, ヨーロ ッパで盛んですが, 湾岸線の沈埋トンネルも世界に誇る ことのできる大型のものです。この工法で問題となるの は水中部分の工事で, セグメントの沈設方法, その継手 方法, 接合後の埋戻し, 及び完成した後の地震に対して の耐力などですが, 湾岸線のトンネルの工事を通じて, 問題点はほぼ解決されたといってよいでしょう。

この他に, 地面を特殊な薬液で涷らせて, 岩盤を掘る のと同じ方法で掘削する凍結工法 (ソ連, カナダで盛 ん，地下水位を低下させるため，予めトンネル予定地 の水を汲み上げてから掘り始める水抜き工法, 圧縮空気 で土圧, 水圧に抵抗させながら行くケーソン工法など がトンネルの作り方としてあげられます。

\section{4. ダムのいろいろ}

もら一つ,土木の大型の構造物としてあげられるのは, ダムです。映画にもなり, 皆様よく御存知なのが, 発電 用のダムで, 日本ではもっとも多いものです。しかし, ダムは発電用ばかりでなく, 同じく土木工学ハンドブッ クによれば,

「河川の流量の多いときに河水を貯留し, 少ないと

きに放流することによって, 水の供給を安定化させ るための工作物」

と定義されています。歴史は古く, B.C. 4000 年に高さ $15 \mathrm{~m}$, 長さ $450 \mathrm{~m}$ の石造ダムがエジプトにできています。

ダムのもっとも普通な形は, 重力式ダムと呼ばれるも ので,自分の重みで水圧に抵抗するものです。この他にア
一チダムと呼ばれる，水圧側に凸のアーチ状の形をした ダムがあります。これは，アーチ橋のところで説明した ように，アーチ作用で水の力に抵抗しょうとするもの で, ヨーロッパでよく作られています。この解析は, 非 常に面倒な計算が多く, 電子計算機の発達とともに数を 増してきました。日本で最近多く作られるようになった ものに, フィルダムがあります。これは，本体は土で作 りますが，乙ゃ水のために，ダム軸付近にしゃ水性のあ る材料を用い，かつせん断強度の高い材料を使って安全 性を高めたダムです。

ダムには, 洪水調節, かんがい, 発電, 上下水道に使 われる貯水ダム, 水の需要に合せて水を供給する調整ダ ム, 大雨時に砂の流出を防ぐ砂防ダムなどがあります。

重力式のコンクリートダムについて述べますと, 基本 形は三角形です。この三角形に水圧が加わった時に，上 流面に直角な鉛直面内の引張応力を生じないこと, せん 断に対して安全で, 圧縮や引張応力度が許容応力度を越 えないことが基本条件です。

施工的には，いろいろな問題があります。ダムは大量 の材料を用いるので，ダム現場付近に良質な材料を得ら れることや,工事用,運搬用の道路が完備していることも 大切なことです。河川の水性きているものであり, ダ ムサイトでは河の流れを一時的に切り替える工事も必要 となります。工事が始ってからは, その重みに耐える支 持岩盤を露出させたり, 岩盤の割れ目から水が浸透しな いようにグラウトの必要もあります。コンクリートを大 量に一時に打設するので, コンクリートの硬化する際に 発する熱を，防止する方策を講ずることも大切なことで す。そのため, 発熱量の少ないセメントを開発したり, 配合に工夫をこらしたり，骨材や水を冷却して用いたり します。またコンクリートは収縮しますので, 継目を設 けて一定箇所に集中させますが，その箇所のグラウトを 行う必要もあります。

いずれにしても, ダムの工事は大規模なもので, 多額 の費用を要しますし, 工期も長くかかります。従って, 綿密な計画をたてて工事を行うことが必要となります。 日本のダムの建設技術は,世界でもトップクラスであり, 一種の輸出技術として海外でも役立っています。 


\section{2 建築のいろいろなコンクリート構造}

建築の少しかわったコンクリート構造として, プレハ ブ工法と，特殊な材料を使った構造について述べましょ ら。

\section{1. コンクリートプレハブ工法}

\section{（1）定義・理由など}

プレハブは英語の prefabrication の省略で，あらか じめ製作するという意味です。鉄筋コンクリートの床ス ラブ・壁・はり・柱などの部材をあらかじめ工場で生産 し，現場で接合して構造体を完成させる工法をコンクリ ートプレハブ工法といいます。プレキャスト（precast） という語も似た意味で使う場合がありますが，これはあ らかじめコンクリートを打込むことで，プレハブの方は 工場生産あるいは大量生産といら, 広い意味を含みま 于。

第 2 次大戦後, 我が国のみならず，欧米各国でコンク リートプレハブ工法の開発研究がすすみ, この工法で多 数の建物が施工されています。開発がすすんだ理由には 次のものが考えられます。
a. 建筑工事量の急増
b. 天然材料（天然骨材・木材など）の減少
c. 熟練労務者の不足
d. 在来工法による企業の前近代性

$\mathbf{a}$ 戦後の人口の都市集中, 経済成長から由来してい ます。需要の急増は, 在来工法では追いつけなくなって きました。bの天然材料の不足は人工材料 (人工軽量骨 材・木製合板など）の普及をうながしましたが，高価な ため, 効率のよい使用法が必要で, これも工法の改革に つながります。c は我が国および欧米先進国に共通な現 象で，プレハブ工法促進の最も重要な理由と考える人も います。建設業のような野外作業がきらわれ，また従来 徒弟制度で養成された職人組織も崩壊したため, 現場の
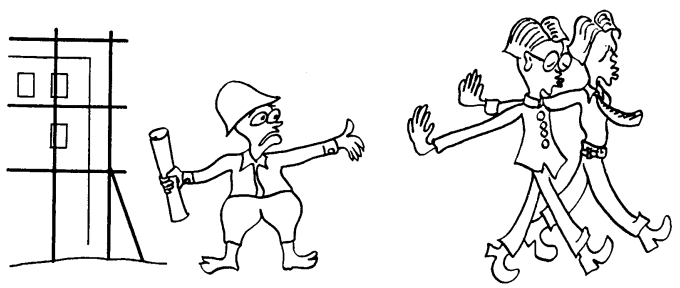

\section{図一1 熟練学務者の不足}

熟練労務者が極度に不足してきたのです（図一1）。これ を補い，かつ大量の需要にこたえるには，労務者の 1 人 当りの生産量を飛躍的に高める方法が必要です。 d は一 般に注文生産に頼る中小企業体が多い建設業界の弱点 で, 工場生産方式を導入して建築の近代工業化をしなけ れば経済の発展に対応できません。このように, 各種の 理由に基づく時代の要求にこたえるためには, 工場生産 を取入れたプレハブ工法が適しているのです。

\section{（2）工法の歴史}

鉄筋コンクリートをプレハブ式に造るといら考えは， 鉄筋コンクリートが発明された初期からありました。そ れは現在ほど現場施工技術が発達していなかったためで

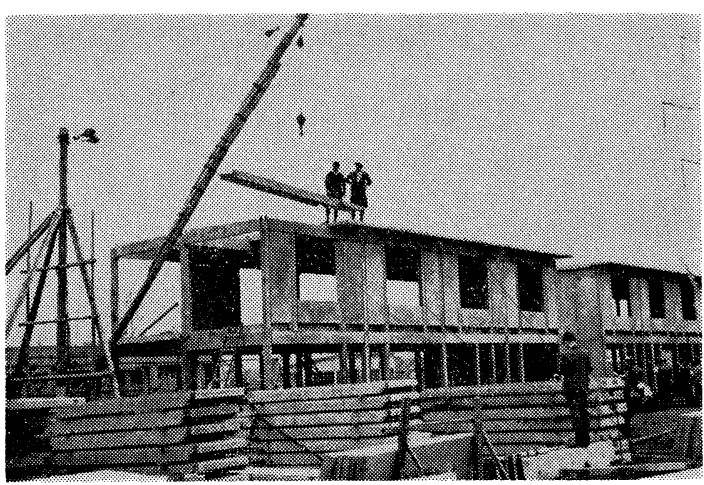

写真一1 プレコンエ法

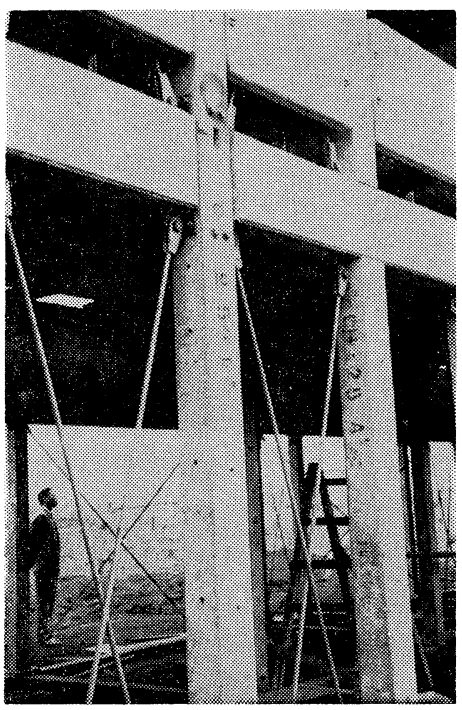

写真一2 プレコンエ法のすじかい 


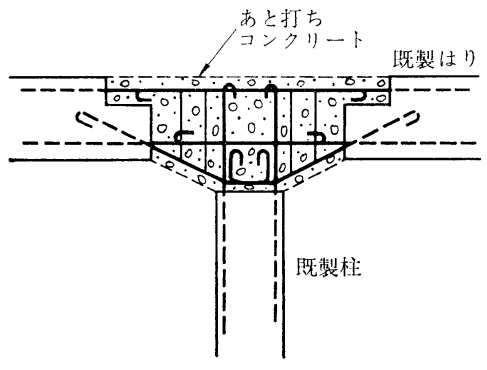

図一2 ラーメン式プレハブエ法

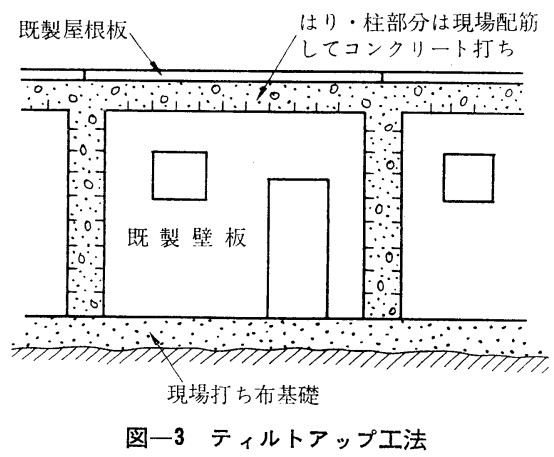

しょう。その後, 現場打ち工法の技 術が進み，それが工法の主流になっ たのですが，需要がふえるにつれて プレハブ化の試みは，また絶えず行 われていました。

我が国では, 第 2 次大戦中に田辺 平学博士が考案したプレコン造が実 施され，戦後も十数年間にわたり， 数多く建設されました (写真一1, 写 真一2)。この工法は，はり・柱・床 板などを工場でつくり，現場でボル 卜で接合し，耐震性のため鋼棒のす じかいを要所に設けるものです。木 造に親んだ日本人にフィットするよ らに, 柱断面は $15 \sim 20 \mathrm{~cm}$ 角程度 にしてありました。

大戦後の建築需要の急増々資材の

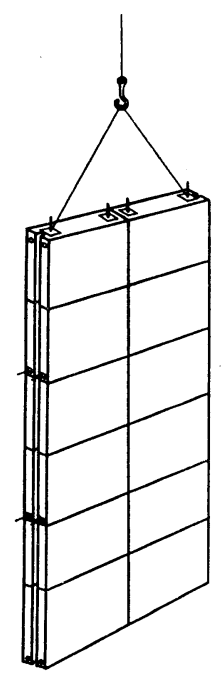

図-4 集成ブロッ クパネル 不足は, プレハブ工法の開発に拍車をかけ，数多くの方 法が発表されました。鉄筋コンクリートラーメンのは り・柱を工場で製作し，接合部のみ部分的に現場打ちコ ンクリートで固める方法（図一2），壁板・床板のみ工場 で製作して現場打ちのはり・柱にはめこむ方法(図一3)， 組積造から発達したコンクリートブロックを用いて, 工 場でブロックを集成したパネルを現場接合して壁式構造 とする方法 (図一4) などたくさんあります。

昭和 30 年に, 全国に大量の鉄筋コンクリートアパー 卜を建設する目的で日本住宅公団が設立され，在来工法

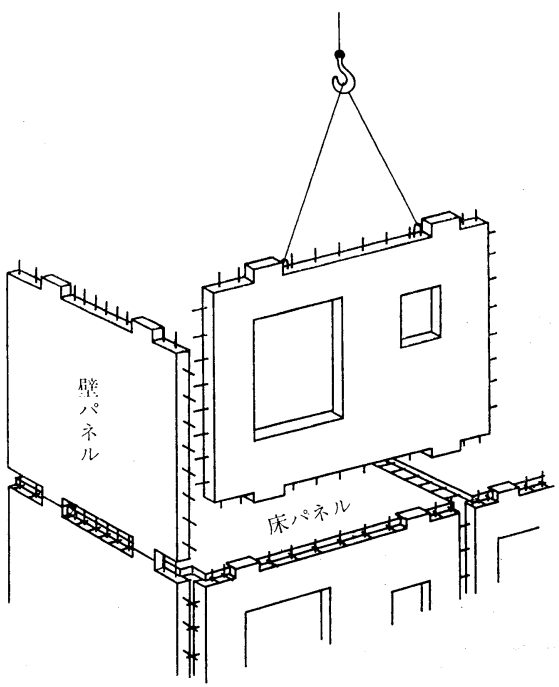

図一5 大型プレキャスト板工法

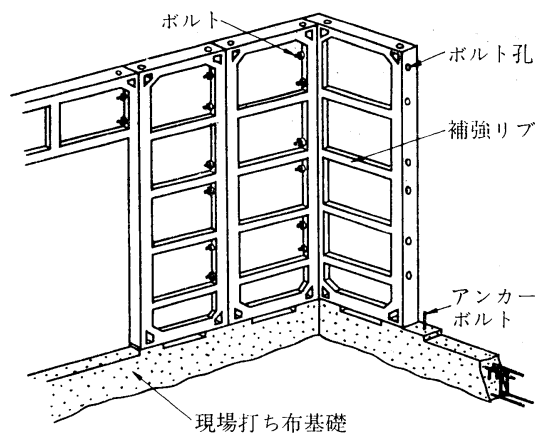

図一6 中型プレキャスト板工法（パネル裏面を示す）

で工事を進めるかたわら，プレハブの研究も積極的に行 いました。公団の方法ははり・柱を持たない，いわゆ る壁式鉄筋コンクリート造をプレハブ化するもので，一 部屋分の大きさ（ルームサイズ）の大型壁板・床板・屋 根板を工場生産し，現場で接合する方法です。接合は， 主として板の端面からつき出た鉄筋あるいは鉄板同士を 溶接し，その上をコンクリートまたはモルタルでおおうう のです (図一5)。

一方，建設省も各プレハブ工法を援助するとともに， 公営住宅用に小規模の壁式プレハブ工法を推奨しまし た。これは中型の板を使うもので，接合はボルトで締め るものです (図一6)。

このような経過をたどり, 官公庁・公団のみならず, 企業もこぞってプレハブ化に熱心になり，現在では相当 数の建物がコンクリートのプレハブで建てられていま す。このなかでは公団が用いた大型板式工法が最も多 く，主流をなしていますが (写真一3)，建物の高層化に ともない,壁のうける力む大きくなるので,壁板に鉄骨で 補強したはり型をつけたもの (HPC 工法) とか, 壁板 


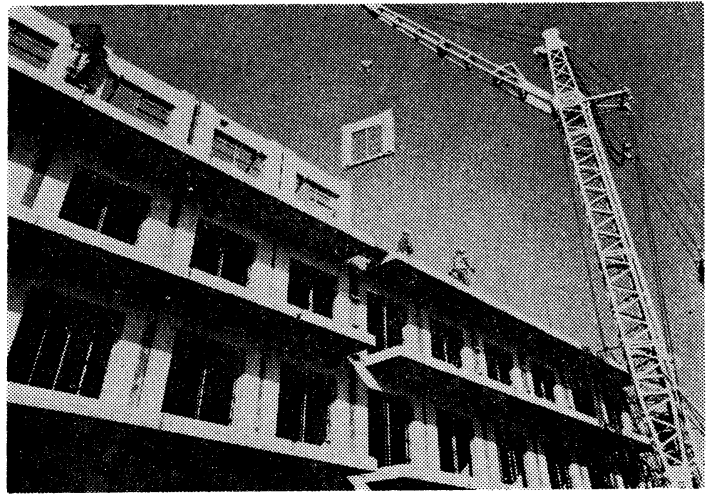

写真一3 大型プレキャスト板の組立て

と組立ラーメンを併用したものとかが現われています。 どの工法にせよ, 構造的に最も重要な箇所は既製部材の 接合部で, 工夫・改良の努力は絶えず行われています。

\section{2. 補強コンクリートブロック造}

洋風建築が明治初期に我が国に伝来した当時の主体構 造は, れんが造の壁体 でした (図一7)。その 後, れんが造はしばし ば地震にあって大きな 被害を生じ, れんがだ けでは強さが不足であ ることがわかり，壁の

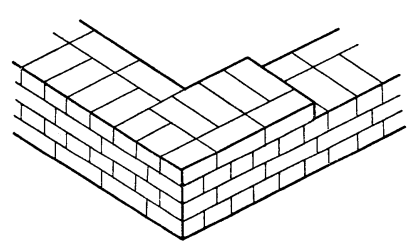

図一7 れんが造壁体
内部の要所に帯鋼などを挿入した補強れんが造が使われ たことがありました。れんが造は，やがて鉄筋コンクリ 一ト造の普及にともなって消滅しましたが，工事にはコ ンクリートの場合のような型わくもバッチャープラント も不要といら, 手軽な簡便さは一つの利点でした。

れんがの代りに，より大きなコンクリートブロックを 組積する工法がその後アメリカなどで発達しましたが, 我が国では第 2 次大戦後まで普及がみられませんでし た。

第 2 次大戦後, 我が国は戦火によって都市住宅を大量 に焼失しました。それらの復興にあたって, 政府が助成 する公営住宅には, 簡便で耐火的な構造が望ましいとい らことになり, アメリカで発達しているコンクリートブ ロック構造に, 我が国に適した耐震性を付加した補強コ ンクリートブロック造が推奨され, 全国に建設されまし た。昭和 20 年代から 30 年代にかけて, 最も多く建設 されています。工法はその後, 若干の改良はありました たが，現在でも実施されています。

補強コンクリートブロック造（通常は補強ブロック造 と略称されます) は, 形態はれんが造と同じく組積工法 Vol. 14, No. 12, Dec. 1976
によっていますが，耐力 的には壁式鉄筋コンクリ ート構造と同じ理論によ っています。組積される 単体コンクリートブロッ クは,アメリカ式になら った三穴形式が標準で, 別に横方向鉄䈘を通すた めの特殊な形のものもあ ります（図一8）。これら のブロックを目地モルタ ルを用いて積上げてゆ き, 各ブロックが隣接す

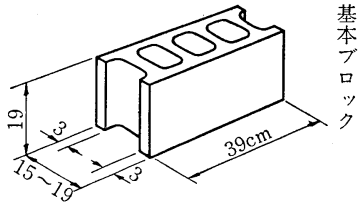

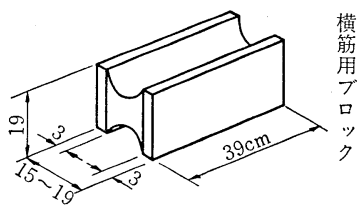

(目地厚さは $1 \mathrm{~cm}$ )

図一8 コンクリートブロック の例 る空洞部（縦目地）には必ずコンクリートを充てんし， 構造規模に応じて，目地ごと，あるいは 1 つおき目地ご とに，維鉄筋を挿入します。通常 3 段ごとに横筋用ブロ ックをおき，この空洞部にも横鉄筋を挿入しコンクリー 卜を充てんします。このようにブロック壁体には綐横に 鉄筋が配置されます。

重要なことは壁体の基部と頂部の補強で, 最下段の基 礎ばり（布基礎が通常です）および各階ごとの壁頂部の 壁ばり (臥梁といいます) は必ず現場打ち鉄筋コンクリ 一トとし, 壁の縦筋は上下端を現場打ちはり部分に十分 に定着しなければなりません。この結果，壁体は上下を 現場打ちのはりではさまれ，縦筋で締付けられた形にな って，壁体内の鉄筋とあいまって丈夫な構造を形成する のです。これは我が国独自の工法で耐震性に富んでいま す(図一9)。外国のブロック構造にはこのような補強が されていません。

このほか, 階数に応じて床スラブや耐力壁の構造や臥 梁の大きさなどが細かく規定されています。構造全体の 壁の量が建物の耐震性 を決定するので，いわ ゆる壁量注1)が壁式鉄 筋コンクリート構造と 同じように定められて います（表一1）。現在， 法的隹められてい る補強ブロック造の規 模・用途は, 3 階建ま貝地コ での住宅・小事務所程 度です。

設計・施工が良好に 行われた補強ブロック 造の構造耐力は大き

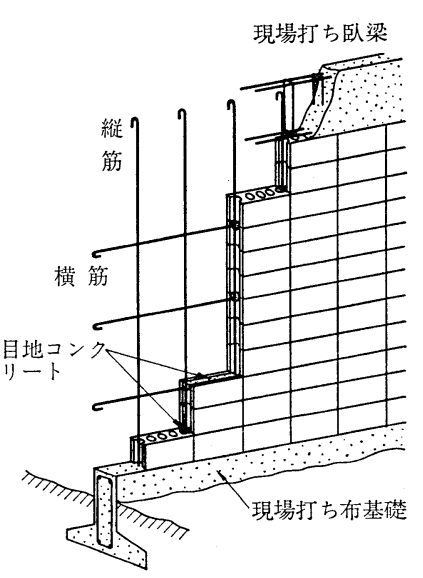

図一9補強ブロック造の壁体
注 1） 3.6 の 2 壁式鉄筋コンクリート構造（本誌10月号） を参照のこと 
表一1＼cjkstart補強ブロック造の壁量規定

\begin{tabular}{c|c|c|c}
\hline 階 & $\begin{array}{c}\text { 標準壁 } \\
(\mathrm{cm})\end{array}$ & $\begin{array}{l}\text { 壁 } \\
\left(\mathrm{cm} / \mathrm{m}^{2}\right)\end{array}$ & 備 \\
\hline 平家または最上階 & 15 かつ $h / 20$ & 15 以上 & $h:$ ブロック積 \\
上から2つめの階 & 19 かつ $h / 16$ & 21 以上 & $\begin{array}{l}\text { み部分の高 } \\
\text { さ }(\mathrm{cm})\end{array}$ \\
上から3つめの階 & 同 上 & 24 以上 & さ \\
\hline
\end{tabular}

く, 過去の新泻地震 (1964 年) や十勝沖地震 (1968 年) にも目立った被害は受けていません。

\section{3. 気泡コンクリート造}

気泡コンクリートは, 正確には軽量気泡コンクリート (Lightweight cellular concrete) といわれ，現場打ち で常温常圧養生のものと, 工場生産で高温高圧養生（オ 一トクレーブ養生）のものとがあります。後者は ALC の略名で日本工業規格 JIS A 5416 に規定されていま す。両者のコンクリートを構造主体に用いた建物を一般 に気泡コンクリート造といいます。

気泡コンクリートとは, 内部に無数の微細な気泡のあ る多孔質軽量コンクリートの総称です注 2 。気泡の直径 は 0.5 1 $\mathrm{mm}$ 程度で, コンクリートの見掛け比重は 0.5 1.2 の範囲です。コンクリートと呼ばれますが, 砂や砂利などの骨材はあまり用いません。原料はセメン 卜または石灰，それに場合により微粉硅砂または人工軽 量砂を用います。製法はそれらの原料と水とを混ぜたス ラリーに発泡剂（アルミニウム粉末， $\mathrm{AE}$ 剂など）を適 量混入して型わくに打込みます。スラリー中で発泡剂に より気泡を発生し，スラリーは膨張したまま硬化しま す。標準圧縮強度は $30 \sim 120 \mathrm{~kg} / \mathrm{cm}^{2}$ 程度です。

気泡コンクリート造は, 壁式構造による住宅・アパー ト・病院などの建築に使われます。多孔質のため断熱性 がよく，また軽量であることが特徴です。オートクレー ブ養生するむの (ALC) は，鉄筋を挿入して一定寸法に 裁断した既製品として販売されますので，これを耐力壁 とする壁式構造に用いるほか，高層ビルなどの間仕切 壁, カーテンウォール，工場などの屋根材に広く用いら れます。

設計法は，現場打ちタイプのものは普通の壁式鉄筋コ ンクリート造と大差はありません。ただ普通コンクリー 卜に比べるとやや収縮性が大きいので，ひびわれを分散 させるために補強筋としては要所の普通鉄筋のほかに溶 接金網 $(10 \mathrm{~cm}$ 間隔メッシュ, 径 $3.2 \phi \sim 5.0 \phi)$ を用い

注 2）製法などの詳細は本誌 1975 年 5 月の軽量コンクリ 一ト特集号参参照のこと
ます。壁式構造としては 4 階建まで認められています。 また鉄骨ラーメン構造に，鉄骨の耐火被覆兼構造材とし て，溶接金網で補強した気泡コンクリートでおおい，一 種の鉄骨鉄筋コンクリート造のように用いる例もありま す。

オートクレーブ養生タイプ (ALC) のものは, 既製パ ネルとしてプレハブ構造に使用されます。パネルには計 算した鉄筋を配置します。標準寸法は，見付幅 $60 \mathrm{~cm}$, 厚さ $10 \sim 20 \mathrm{~cm}$, 長さは $6 \mathrm{~m}$ 程度までです。壁パネル はシングル配筋ですが，屋根・床パネルはダブル配筋で す（図一10)。壁式構造として使用する場合は，補強ブ ロック造と類似の規定があって，現場打ち鉄筋コンクリ 一トの布基礎と卧梁の設置が義務づけられています。パ ネルは縦に使らのが普通で, パネル間には目地鉄筋を, パネル端には曲げ補強筋を配し，それぞれ上下の現場打 ち臥梁および布基礎に定着します（図一11)。そのほか， 各階ごとに補強コンクリートブロックや壁式鉄筋コンク リート造と同じく壁量の規定があります。現在耐力壁構 造としては，2 階建まで認められています。

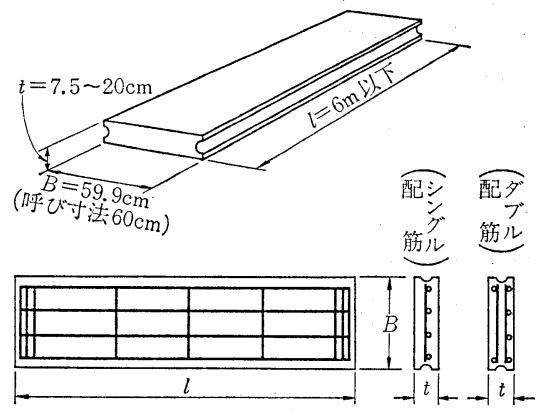

配 筋 図

図一10 ALC パネル

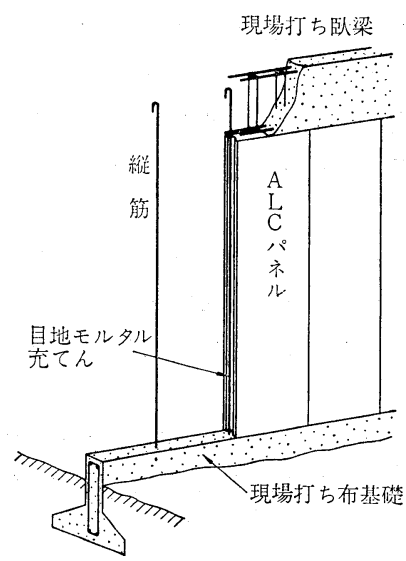

図一11 ALC パネル耐力壁 


\section{5. エピロ グ}

未来のコンクリートー

\section{古賀夫人の淡い夢}

ある日, 誠一君が学校から帰ってくるなり, 古賀さん の奥さんに,

「明日，健ちゃんの家へ行っていい?」と頼んだ。

「宿題で “未来の...........”書くんだけど，僕は “未 来のコンクリート”を書こうと思うんだ。実は清川さん の都合もきいて，OK取っているからいいでしょう。」

「清川さんの御都合が良ければいいけど…...折角の お休みだから, 余り御迷惑にならない程度にしていらっ しゃいよ。」と答えながら，古賀さんの奥さん山，漠然 と誠一君が将来土木屋—それもコンクリート構造技術 者になるように感じていた。毎月清川さんから送られて くる「コンクリート工学」の教室を熱心に読んでいた し, 電話で分からないところを質問をするなど, 誠一君 が, コンクリートに非常に興味を持っているのは事実だ った。御主人も笑いながら，「誠一が土木屋になりそうだ から，健ちゃんに俺の跡を継いで黃うかな。」話して いる位である。

奥さんが，娘時代の “恋を恋していた年頃”に，土木 の大学生だった従兄と “佐久間ダム” の映画を見たこと がある。映画を見終った後，ダム技術者の中に真の男ら しさと仕事に対する真摰性を感じ, dark, tall and handsome の理想の男性像を見出したものだった。

まだ理屈ぽかった従兄が，

「世の中で言われているのと反対に，男は romantic だが，女性は prosaic なので，この映画に男は感激して ダム屋は増えるだろうが, 逆に女性は山の中での非文化 的な生活に辟易して, 嫁さんのなり手がなくなるんじゃ ないかな。もっとも教授の奥さんが, 一一結婚して 20 年 たっているらしいが—この映画を見て土木屋の偉大さ を始めて認識して，御主人を見直したそうだけど…… これは例外だろうなっと感想を述べたのに, “ここにだ ってロマンティックな娘はいるんですよ。と反発し，そ の日はあまり口をきかなかったことも, 合せて想い出し た。

誠一君がどんな種類の土木屋になるにしろ，古賀さん の奥さんの淡い夢が, 誠一君によって実現されるように 感じていた。

\section{コンクリート材料の将来}

「まず材料の点から，コンクリートを見てみようか。」 と清川さんは話し始めた。

「商品としてセメントを見ると，セメントの生産量は 年々伸びており，ライフサイクルを表す $\mathrm{S}$ 字形成長曲線 の最終段階 (成熟期から後退期)には，まだ達していない。 さらに,現在でもセメントの価格は安いし,使用の伸び率 を見ていると, 代替物の出現は当分なさそうな点から も,将来にわたって,セメントはまだまだ十分に使われる 材料であることは間違いないようだ。この辺は，お父さ んが詳しいからきいてみるといいよ。少し難しいかな。」

「あまりはっきりしませんが，大体分かります。セメ ントの世界にも, 経済が関係するんですね。」と誠一君は 感心したように答えた。

「技術者は,どうもそこまで考える人がいなくてね。広 中さんが言っているように, consumers' price を絶え ず考えることが，これからの技術者には必要だね……。

別の見方をすると，現場に抢ける生産能力は年々増加 して行くし, ある単位——例えば建築容積でいいがに対して, 材料の重量は年々減って行く。このことは, 材料の単位重量あたりの価格は上昇して行くことを示し ている。この上昇曲線がセメントについてみると, まだ まだ, 他の材料に比べて下位にあるので, 当分大丈夫の ようだ。

次に骨材の問題だが, 絶えず不足勝ちという声はあ り，20 年位前から言われているが，依然として供給は続 いている。ただ採取する場所注，段々変わっていること は事実だし，現状では相当無理して採っている。しかし 先程の話にあったように，他の材料との比較で考えた場 合, 現在の価格で採算ベースには合わなくとも, 将来的 には十分ペイするだけの骨材の貯蔵庫はあるようだから 安心だ。」

誠一君は, 不思議そうな顔で,

「具体的にどういらことですか?」と尋ねた。

「例えば，相当古くなったダムには土砂が堆積してい るし，畑の砂とか，海の砂利を使うといら手もあるし… …。再生産といらことも考えられる?」

「再生産というのは?」 
「世の中の進歩とともに，不用になったコンクリート 構造物は沢山あるね。これを壊して骨材を再使用するこ とになると，無限のサイクルになって，骨材の不足に悩 まされることはなくなる訳だ。」

「なるほど。宇宙船で，水や食糧を供給するのに，人 間の排泄物を再加工するのと同じです叔……」と誠一 君が答えたのに対し，清川さんも笑いながら，

「いい所に気がついたね。全く同じだ。」と応じた。

「骨材の不足と先程の建築容積あたりの材料の重量の 軽減を図る目的で，軽量人工骨材が出現したが，それと 同じ発想でコンクリートに高い引張強度を持たせる混入 材料も将来は出てきそらだ。鉄筋や P C 鋼材の材料強度 の上昇の他に, 現在研究段階の高分子材料や人造䋐維の 開発も進むだろうし......., ただ現在では, 值段的にコン クリートの数千倍もするので無理だが........ その場合に は,現在の形のコンクリートとは異なったものになり,果 たしてコンクリートといら名前で呼ばれるかどうかね。」

「ジュースと同じで, 天然セメント入り（？）コンク リートというのも出来ますね。」と誠一君が真面目な顔 で茶化したので, 清川さんはふき出してしまった。

\section{施工技術の変化}

「コンクリートの未来を語る場合は, どうしても材料 の事が一番先になるが, いずれまた戻るとして, 次に施 工の面から見てみよう。コンクリートの良い面として現 場で自由に色々な形が出来るといらのがあったね。また 悪い面として, そのために色々な設備と人手が現場で必 要になるといらこともあったね。コンクリートの将来性 を語る場合には, その良い点を生かしながら, 設備と人 手を如何に少なくできるかが焦点となる。

材料の輸送の問題から考えると, やはりパイプ輸送が 本筋になると思う。車輪の回転運動で, 物資を移動させる といらのは，過去 4〜 5千年も続いた輸送システムだが， 公害問題その他からも，何れはパイプ化されるだろう ね。それぞれの材料を素材のままでパイプ輸送するの は，すぐだろうが，そのうち水道の栓をひ㐎をと水が出 るのと同じように，コンクリートがでてくる時代が来る かも知れないよ。」

「ええ・コンクリート蛇口ですか？」と誠一君は目を 丸くした。

「まあ一種の夢だろらが.......。それとコンクリート製 品がプレハブ化され, 工場で大量生産を行って, 半製 品として出荷され，ホーバークラクトやへリコプターで 現場まで運び, 組立てる, といらのも先程の欠点の解消 につながるね。さらに現在みたいに，コンクリートの中 に鉄筋を入れたり, 他の補強材を入れたりする代りに,
いくつかの組材をサンドウィッチ状に接着して, 強度を あげることも，工場製品なら可能だろう。それらは施工 精度の上昇にもつながるし，いずれにしても，プレハブ は次の時代のコンクリートの一面だね。」

「要するに, インスタントコンクリートですね。」と 誠一君がチャチを入れた。

「インスタントといらより，プラモデル化かね。もら 一つは, 品質管理の方法の進歩があるね。現在は, 28 日 なり, 91 日経ってからでないと, コンクリートの強度は 分からないが，そのうちに軟かい時期に強度が判定可能 になる。もし低いと,放射線を吸収させて強くしたり,乾 燥収縮が多そらだと，少なくするものを注入したり……。 さらに硬化してからでも，内部組織までX線やアイソト 一プの作用で強度が分かるようになるとか……」

「さっきからチャチを入れて申訳ありませんが,八マチ に注射しておいしそうに見せるとか，りんごに注射して 赤く見せるのと同じですね。」と誠一君が言葉を狭んだ。

「世の中は，どこも同じで，コンクリートの世界も似 たようなものだよ。と清川さんも応ずる。

\section{設計の方法は？}

「設計の面では，どのように変わりをすか？」

「いい質問だね。コンクリートが現在の形である場合 は，設計図に合せて構造物を作るといらのが一応の手順 だが，将来は構造物のレイアウトに対して，設計図を 合せて行くという時代になる㸚。コンクリート材料の進 歩で, 強度は増加し, とくに引張強度は強くなり, 薄い 部材でも可能になるので, まず望ましい構造物のスケッ チを描いて，それを計算で補いながら，設計図を描くと いらことになる。これからの設計者には，絵の才能が要 求されるね。」

「それじゃ，僕も絵を勉強しなければ……。」

「もら一つは，設計の標準化が進むね。体に背広を合 せるのでなく，背広に体を合せることも，コストの点で 必要になってくる。外出着はオーダーメイドで, 仕事着 はレディメイドという形だが……。このことは標準的な 仕㥞書が完備することを意味しているし，現実的で無駄 のない制限の少ない示方書が生まれることになる。さら には，コンクリート技術者でなくても，プラモデル化と 相まって，カタログさえ見ると，建物を作れる時代の到 達となる訳だ。」

\section{これからのコンクリート構造物}

「最後に伺いますが，将来はどんなコンクリートの構 造物ができるんですか?」 
「以前“コンクリート工学”で会員から，“100 年後の コンクリート”でアンケートを取ったことがある。その 中で将来どんな方面でコンクリートが使われるかという 問に対して, 海洋開発, 超高層構造物・地中構造物（鉄 の代りにコンクリートで),船舶, 宇宙開発,長大スパンの 橋りょう, 自動車のボディ, 家具の順で回答が寄せられ た。これらは，現在でも通用する予想の集約だろうね。」

「宇宙開発というのはどんな形ですか？」と誠一君が 不思議そうな顔をした。

「水なしで固めることができるセメントができて，水 のない月世界などで開発に使われるというんだよ。」

「なーるほど。そうするとセメントだけを宇宙船で運 んで，月の岩石を骨材として使って工場を作って，そこ でセメントを生産して……と続く訳ですね。」と誠一君 が自ら解説した。

「それは少し夢すぎるが，もっと身近な所ではやはり 水上都市とか水上空港だろらね。今の人口の増え方から するとそれは必然だし，コンクリートの耐久性からいっ て他の材料よりは有利だ。発電所も陸上じゃ建設は無理 になって水上に移り，原子力発電にでもなると，耐熱 性の点でコンクリートは有利だし……。䏠れにしても 人間が水上に移るか, 諸産業が水上に移るかの何れかだ から，その面でのコンクリートの使用は伸びるよ。地下 というのも同じ発想だね。

また，地上に建物があるにしても，建物は，今のよう に横に連ねて居住空間を作るのでなく, 縦に連ねて居住 空間を確保することになり，高層ビルは増えていくね。 その場合も, 使用目的に合わなくなったり, 古くなった りすると，その部分を抜き出して取換え，ビルそのもの は，維持することも夢ではなさそうだ。もちろん 100 階 建位のビルになるだろう。

高速道路の面から見ると, 現在のアスファルトは, 石 油資源の涸渴から高くなるだろうし，コンクリート以上 に骨材を使うんで, 舗装は, コンクリート舗装に徐々に 変わっていくだろうね。この場合も，プレキャストのパ ネルスラブが大いに使われて,補修も簡単になるし…… 一方，人間が海上に移るようになると，そのための高速 道路用の橋が必要になってくる。そうすると施工性から いって,長いスパンの橋が望ましい。現在, 大体 10 年で $50 \mathrm{~m}$ ずつ, コンクリートの橋のスパンが伸びているか ら，500 m のコンクリートの橋は目前だね。

将来, 鉄道も時速 500 ～1000 km になるだろうが，そ うすると磁気の関係で鋼は使えなくなり，コンクリート
が大いに使われることになるだろら。勿論, 製作精度が 現在の5 10 $\mathrm{mm}$ から $0.1 \mathrm{~mm}$ 程度まで上がることを子 想しての話だが……

船舶というのも面白い夢だが，すでに一部の水中資源 の開発に使われ始めている。これもひびわれのない軽い コンクリートの出現ということで, 加工性から有利な点 だね。

別の観点から，強いコンクリートといら他に，弱いコ ンクリートがでてくるね。」

「弱いコンクリートというのは何ですか？」と誠一君 が尋ねた。

「弱いといったって，必ずしも強度的に弱い訳でな く，不必要になったものを簡単に壊せるといら意味で弱 いものだが…..。これは骻材の問題とか環境の問題から 是非必要になってくる。

今後人間は, ますます睱で, 贅沢になって行くと思 う。そうすると，自分の家をレジャーとして建てたいと いうことも考えるだろうね。それも先程のプレハブ化と も関係して，カタログと首引きで，パネルの接続部をボ ルトでとめるとか, 自分でコンクリートを練って, 打込 むなんていうのも意外に面白いレジャーとして受けるか も知れない。これが，自動車のボディとか，家具まで発 展していくだろうが…...

最後に一言。コンクリートの色は環境とマッチしたも のという考えから, 灰色一色から, カラフルなものに変 わって行くことをつ汁加えたいね。もっとも一般人の美 的感覚の変化が, 灰色の方が美しいというように変わる かも知れないが，私は，現在の感覚がそのままで，コン クリートの方が変わって行くと思らよ。」

「どうもありがとうございました。今日のお話をまと めて，宿題を仕上げます。」と誠一君がお礼を述べた。 最後に清川さんが,

「今日は, 久し振りに学生時代に帰った気分だよ。夢 というのは, 発展とか進歩の基礎だからね。いずれにし ても, 土木とか建築の技術者だけで夢を追っても無意 味で,地球人類全員が,あらゆる知識を動員して, 健全な 考え方を育てつつ，はるか彼方の理想の水平線を追って 行くことが最も大切なことだよ。と結んだ。

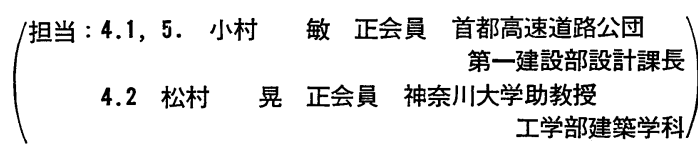

